\title{
Local Political Dynamics in the Issue of Expansion of Mining Areas in Bone, Indonesia
}

\author{
Nursaleh Hartaman ${ }^{1,2^{*}}$, Miftahul Rahman ${ }^{2}$, and Muhammad Yusuf ${ }^{3}$ \\ ${ }^{1}$ Universitas Muhammadiyah Makassar, Indonesia \\ ${ }^{2}$ Pusat Penelitian Ilmu Sosial dan Humaniora Kontemporer, Indonesia \\ ${ }^{3}$ Universitas Muhammadiyah Makassar, Indonesia
}

\begin{abstract}
Local political dynamics emerged due to the proposed changes in spatial and territorial layout in Bone Regency. If passed, the policy would increase the area of the mining area, meanwhile it is feared that additional mining areas will cause environmental damage. The research method used is qualitative by conducting interviews with several sources and making observations at the research location. The results showed that the mining area in Bone Regency which was originally 12 sub-districts will increase to 27 sub-districts if the spatial planning regulations regional regulation is passed. The government believes that increasing the area of the mining area in bone district will have a positive impact on local revenue, but this dynamic continues because there are still some protests from environmental activists. Not only that, the regional regulation on Regional Spatial Planning in Bone Regency also has to wait for synchronization with the spatial planning regulations at the provincial level.
\end{abstract}

\section{Introduction}

Indonesia is a country in the mineral belt (the rim of fire) with high mineral potential. When compared to other countries in Asia, Indonesia leads in the production of copper, gold, silver, nickel, tin, and coal [1]. In general, it is widely acknowledged that the blessings of abundant natural resources can be an advantage for a developing country which in general are countries rich in natural resources. its origin is often debated or controversial among scholars or scientists in this field, specifically on its breadth and impossibility to avoid. However, the fact that a country with abundant natural resources is a curse tends to strengthen and become more real [2,3]. Natural resources can be managed well with good political power [4] Politics can play a major role in recasting the lives of many people in society, either for good or for personal gain. Good politics implies a good life and vice versa, bad politics implies a bad life [5,6].

Natural resource management can lead to political dynamics if it is not managed properly $[7,8]$. In fact, the constitution mandates that the earth, water, and natural resources are controlled by the state and used as much as possible for the prosperity of the people. The constitutional mandate is in accordance with the principle of democratic socialism which opens up opportunities for state intervention in the management of natural wealth but must be for the benefit of the people. Therefore, every government policy related to natural wealth must be populist with an emphasis on the distribution of mining products for the

\footnotetext{
* Corresponding author: nursaleh1994@gmail.com
} 
holders of sovereignty, namely the people. but in reality, the management of natural resources, especially mining goods such as minerals and coal is not as easy as imagined, because many interests play behind it [9]. Instead of thinking about the interests of the people, the government has left the management to foreign investors with the consideration that it will increase state revenues more quickly. As a result, in many cases, it is precisely in areas where there is great mining potential, but the people around them are still poor. Furthermore, when management is handed over to foreign parties, even though the exploitation of natural resources is increasing rapidly, it is still followed by low manufacturing growth [10].

Bone Regency is an area that has a wealth of abundant natural resources, so the government seeks to optimize local revenue through the use of natural resources spread over 27 sub-districts. Currently, according to the spatial planning regulation 2013 of Bone Regency, there are only 12 sub-districts that can become natural resource mining areas, so there are 15 sub-districts that should not be exploited into mining areas. In 2020, the regional government proposed changes to the spatial planning regional regulation which included changing the mining area from 12 sub-districts to 27 sub-districts, which means that all sub-districts in Bone Regency can become mining areas. The proposal to change the regulation creates political dynamics where there are some environmental activists who think that if the spatial planning is legalized, it is feared that it will have an impact on environmental damage. this is an interesting problem to study how the political dynamics with the proposed changes to the expansion of the mining area in bone district.

\section{Methods}

This study uses qualitative methods using research procedures that produce descriptive data in the form of written or spoken words from people and observable behaviors using secondary data as the main analysis of the study [11]. The process of data analysis in this study was carried out by triangulation [12], namely data reduction by summarizing, looking for things that are important or core so that the data can be seen clearly. Then the presentation of data by displaying data in a qualitative research type, the last step is verification with evidence that is considered valid and consistent when the researcher returns to the field of observation, then the conclusion is credible.

\section{Result and Discussion}

Determining a suitable zone/area is a process to determine the area to be proposed in the Regional Spatial Plan as a mining business activity. So that the core of the activity in determining a mine-worthy zone/area is to determine the criteria that determine the mining area and then carry out an ideal screening to get the area to be proposed. The Mining Area in Bone Regency is an area located in a mine-worthy zone in which there is a distribution of superior minerals. This area is prepared in an integrated manner as well as to utilize superior materials to meet the current and future needs for mineral resources. Government policies are needed to manage the mining area so that the area is ready to be developed.

The potential of natural resources in Bone Regency is indeed very abundant. The proposed amendment to the Spatial and Regional Plan has created political dynamics at the local level, some environmental activists have asked that the change to a mine can be reviewed because if all sub-districts become mining areas, it is feared that it will cause environmental damage. This concern was then answered by the Head of the Industry Office of Bone Regency that expanding the mining area is not to damage the environment but to change and utilize natural resources to increase the original regional data collection. 
The Head of Industry of Bone Regency conveyed that 27 sub-districts in Bone were proposed to be included in the mining area and the process is currently ongoing. The Department of Industry considers mining to change the environment, not damage the environment depending on how it is managed. There are 12 sub-districts in Bone Regency that are allowed to be included in mining areas, according to Regional Regulation 2/2013 concerning Mining Areas. The 12 regions are Sibulue, Ponre, Kajuara, Kahu, Bontocani, Patimpeng, Libureng, Lamuru, Ajangale, Salomekko, Palakka, and Lappariaja sub-districts. Later, if the proposed Regional Spatial Plan amendment is approved, the distribution of the mining area will spread throughout the Bone Regency area as shown in Figure 1.

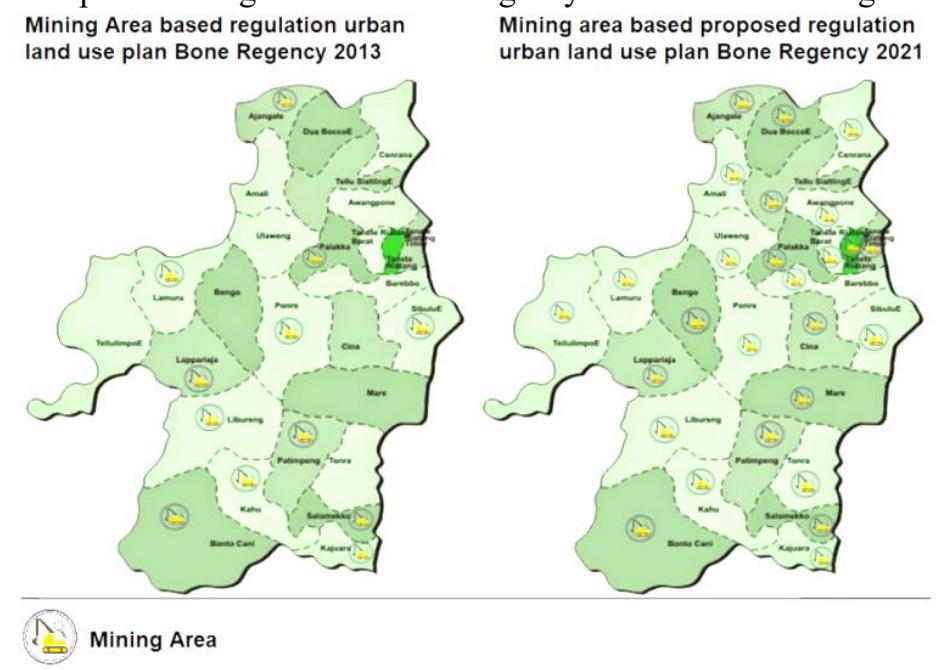

Fig.1. Map of changes in mining area expansion in the proposed spatial planning regulation change

The change in the mining area proposed by the government eventually creates political dynamics because the entire area can become a mining area and there is no longer a conservation area so that until now the changes to the spatial planning regulation have not been ratified. Several conflicts have occurred due to mining problems in Bone Regency, such as the rejection of the marble mine in Bontocani District in December 2020 by the Reject Mining Alliance by submitting a demand that the provincial government revokes the mining business license of companies operating in Bontocani District. This refusal occurs because mining activities are considered to make the community restless due to the threat of environmental damage. The company has never performed an environmental impact analysis.

This dynamic must be understood as a democratic process to find the best way in natural resource management. Good natural resource management will have a positive impact on the development of local revenue which will be used for the public interest [13] The strongest reason for the expansion of the mining area in Bone Regency is the abundant mineral potential, this potential is spread almost throughout the Bone Regency area, the distribution of mineral potential can be seen in table 1 .

Tabel 1. Potential Minerals and Rocks of Bone Regency

\begin{tabular}{|c|c|c|c|c|}
\hline No. & Minerals & $\begin{array}{c}\text { Location } \\
\text { (District/Village) }\end{array}$ & $\begin{array}{c}\text { Chemical Properties and } \\
\text { Formation }\end{array}$ & Potential Content \\
\hline 1 & Coal & $\begin{array}{c}\text { Lappariaja, Lamuru, } \\
\text { Kajuara, Kahu }\end{array}$ & $\begin{array}{c}1-4 \% \text { Sulfur ; 8 - 11\% Water } \\
\text { Content ; 3 - 13\% Ash ; 20 - }\end{array}$ & Calories 4.626.300 Tons \\
\hline
\end{tabular}




\begin{tabular}{|c|c|c|c|c|}
\hline & & & $\begin{array}{l}36 \% \text { Flying Substance; } 5.100 \text { - } \\
6.800 \text { heat }\end{array}$ & \\
\hline 2 & Manganese & $\begin{array}{l}\text { Ponre, Libureng, } \\
\text { Salomekko and } \\
\text { Bontocani }\end{array}$ & $\begin{array}{l}\text { - Float Pyrolusite } \\
\text { - Float Psilomelan }\end{array}$ & $\begin{array}{l}-67,281 \text { Tons } \\
\text { - Bontocani in the form } \\
\text { of Ferromangan } 10 \\
\text { Million Tons }\end{array}$ \\
\hline 3 & Copper & $\begin{array}{l}\text { Libureng, Ponre and } \\
\text { Patimpeng Tonra }\end{array}$ & $\begin{array}{l}10 \% \mathrm{Cu} ; 13.4 \% \mathrm{Mn} ; 1.6 \% \mathrm{~Pb} \\
0.3 \% \mathrm{Zn} ; 300 \text { gram/ton } \mathrm{Ag}\end{array}$ & Unknown \\
\hline 4 & $\begin{array}{l}\text { Gold } \\
\text { Silver }\end{array}$ & $\begin{array}{l}\text { Libureng, Ponre and } \\
\text { Patimpeng }\end{array}$ & Influence ofIntrusion & Unknown \\
\hline 5 & Iron Ore & $\begin{array}{c}\text { Bontocani, Kahu and } \\
\text { Libureng }\end{array}$ & Magnetite; Hematite & $116,682,200$ Tons \\
\hline 6 & $\begin{array}{l}\text { Sand } \\
\text { Quartz }\end{array}$ & $\begin{array}{l}\text { Lappariaja, Lamuru, } \\
\text { Kahu, Kajuara, } \\
\text { BONTOCANI }\end{array}$ & $\begin{array}{l}\text { Color dirty white to brownish- } \\
\text { yellow, medium-grained coarse } \\
\text { content } \mathrm{SiO} 95.75 \%\end{array}$ & $12,844,000$ Tons \\
\hline 7 & Clay & $\begin{array}{l}\text { Lappariaja, Lamuru, } \\
\text { Cina, Tanete Riattang. }\end{array}$ & $\begin{array}{l}3,21-9,85 \% \text { AI203; } 1,78- \\
3,13 \% \text { Fe203; 0,10- 2,62\% } \\
\mathrm{CaO} ; 0.14-6.81 \% \mathrm{CaO} ; 51.33 \\
82.85 \% \mathrm{Sio} 2\end{array}$ & $\begin{array}{l}\text { - Lappariaja (10M m3) } \\
\text { - Cina (10M m3) } \\
\text { - Bukaka (1M m3) }\end{array}$ \\
\hline 8 & Limestone & $\begin{array}{c}\text { Ajangale, Amali, } \\
\text { DuaboccoE, Ulaweng } \\
\text { Palakka, Barebbo }\end{array}$ & $\begin{array}{l}\text { Taccipi Limestone Walanae } \\
\text { Formation }\end{array}$ & Millions m3 \\
\hline 9 & Marble & $\begin{array}{l}\text { Bontocani, Ulaweng, } \\
\text { Tonra, and Kahu. }\end{array}$ & Tonasa Formation Limestone & $\begin{array}{l}-1,068,375,000 \text { Tons } \\
-631,625,000 \text { Tons } \\
\text { - Tonra unknown }\end{array}$ \\
\hline 10 & Koalin & Kajuara & $\begin{array}{l}\text { Intrusion Influence of Diorite, } \\
\text { Trakhite and Granodiorite }\end{array}$ & Unknown \\
\hline 11 & Sirtu & $\begin{array}{c}\text { Kajuara, Salomekko, } \\
\text { Bengo, Ponre, } \\
\text { Lappariaja, Lamuru, } \\
\text { Tanete Riattang west, } \\
\text { Bontocani, Liburang, } \\
\text { Tonra, Mare, Cina, } \\
\text { Kahu, Awangpone } \\
\text { River }\end{array}$ & Alluvial Sediment & Unknown \\
\hline 12 & Limestone & Bontocani & (Tonasa Formation) & $1,378,400,000 \mathrm{~m} 3$ \\
\hline 13 & Limestone & Ponre and Libureng & (Tonasa Formation) & $\begin{array}{l}202,376,600 \mathrm{~m} 3 \\
3,750,000 \mathrm{~m} 3\end{array}$ \\
\hline 14 & Limestone & Cina & (Dolomitan Formation) & $23,250 \mathrm{~m} 3$ \\
\hline 15 & Rhiolite & Tonra & $\begin{array}{l}\text { Influence of Frozen Rock } \\
\text { Intrusion }\end{array}$ & 160 ha \\
\hline 16 & Granite & Kahu, Bontocani & Influence of Frozen Intrusion & Rock92,160,000 m3 \\
\hline
\end{tabular}


The data above shows that the potential for natural resources in Bone Regency is indeed very large, almost all sub-districts have abundant mineral content. If all these resources are managed properly, the Potential for Regional Original Income (PAD) from the mining sector in Bone Regency will increase. The contribution of the mining as a Source of Regional Original Income can reach 2.4 billion Rupiah. However, until now this potential has not been maximized because the proposed changes to the mining area must be adjusted to the spatial and regional planning at the provincial level.

Government policy is of course very necessary to manage mining areas in Bone Regency so that the area is ready to be developed. The mining area concept itself is characterized by the following principles:

1. The determination of the mining area must be based on the consideration of optimizing the utilization of natural resources as a function of time through the calculation of the analysis of benefits and costs, so that the utilization of mineral resources in the area can provide greater benefits than the exploitation of other natural resources.

2. Determination of mining area means that the area will determine the mining sector as a priority and as a driver of development and development of other leading sectors.

3. Mining areas take into account local socio-cultural aspects, aimed at optimizing the value of mining and the benefits of minerals for the community and local government.

4. Mining areas make it easier for investors who are interested in developing a business in the mining sector and related businesses in it but still have to follow all applicable rules.

These four principles must be met so that natural resource management can be maximized and have a positive impact on the common interest in Bone Regency.

The dynamics of local politics in Bone district due to the expansion of the mining area can allow for the creation of true democracy if it is not only seen from the views of optimism and pessimism, but also looks at both views and finds a way out of the problem. Now what needs to be asked is about the time to realize local politics in peaceful natural resource management so that it can prosper the community in the current and future context.

\section{Conclusion}

The potential of natural resources in Bone Regency is very large, almost all subdistricts contain abundant minerals. If all these resources are managed properly, the Potential for Regional Original Income from the mining sector in Bone Regency will increase. The contribution of the mining as a source of Regional Original Income can reach Rp. 2.4 billion every year. However, this potential has not been realized because the proposed changes to the spatial planning regulations governing mining areas have not been legalized and have created political dynamics at the local level. These dynamics can enable the creation of true democracy if it is not only seen from the perspective of optimism and 
pessimism, but also from both perspectives to find a way out of the problem and realize the peaceful management of natural resources so that it can prosper the community in current and in the future.

\section{Reference}

1. M. H. Anshori, J. Masy. Budaya 18, 433 (2016)

2. Barma, K. Kai, T. Minh, and L. Vinuela, Rents to Riches? The Political Economy of Natural Resource-Led Development (@) World Bank, 2012)

3. P. Collier, Soc. Res. J. 77, 1105 (2010)

4. P. A. Walker and P. T. Hurley, Soc. Nat. Resour. 17, 735 (2004)

5. N. Hartaman, T. Purwaningsih, and A. Nurmandi, J. Gov. 5, 31 (2020)

6. A. Ichuloi, Int. J. Humanit. Soc. Sci. Educ. 5, 16 (2018)

7. M. Chêne, Natural Resource Management Transparency and Governance: A Literature Review Focusing on Extractive Industries (CMI Michelsen Institute, Germany, 2017)

8. T. Sterner and J. Coria, Policy Instruments Environ. Nat. Resour. Manag. Second Ed. 1 (2013)

9. J. Hamidi, Law, Policy Glob. 44, 80 (2015)

10. N. Yuwana, H. Nugroho, and I. Abdullah, J. Pemikir. Sosiol. 1, 1 (2015)

11. J. W. Creswell, "Research Design. Pendekatan Metode Kualitatif, Kuantitatif, Dan Campuran. Edisi Keempat.”. (Pustaka Pelajar, Yogyakarta, 2016)

12. S. Sugiyono, Penelitian Kualitatif Dan Kuantitatif (Graha Medika, 2014)

13. M. Habibi and S. Suswanta, J. Gov. Public Policy 6, (2019) 